\title{
Beyond the North-South Dichotomy in International Climate Law: The Distinctive Adaptation Responsibilities of the Emerging Economies
}

\author{
Daniel Farber
}

This article focuses on uneven development within emerging economies. The result of this unevenness, which often separates urban from rural populations, is that emerging economies contain two large groups: one that is enjoying rapid economic growth and begins to see a trajectory toward developed country lifestyles, and another that is lagging behind and is still more similar to developing country residents. In short, an emerging economy can be seen as containing within itself a quasi-developed country and a quasideveloping one. The article argues that these internal divisions are distinctive to emerging economies and that they provide a basis for differentiating the responsibilities of emerging economies from the developed/developing country situations. Internally, populations within emerging economies have common but differentiated responsibilities themselves, and emerging economies have a duty to use national resources funded by the more developed portion of the society to assist with adaptation in less-developed areas.

\section{INTRODUCTION}

The concept of 'common but differentiated responsibilities' has long been part of discussions about climate mitigation. The same concept now plays a role in terms of climate adaptation. ${ }^{1}$ According to the Cancún Agreements, '[e]nhanced action on adaptation ... should follow a country-driven, gender-sensitive, participatory and fully transparent approach, taking into consideration vulnerable groups, communities and ecosystems'. ${ }^{2}$ Moreover, the Conference of the Parties '[i]nvites all Parties to enhance action on adaptation ... . taking into account their common but differentiated

\footnotetext{
${ }^{1}$ Adaptation requires society to manage climate impacts using strategies of resistance, adjustment and retreat. See R.M. Verchick and A. Hall, 'Adapting to Climate Change While Planning for Disasters: Footholds, Rope Lines and the lowa Floods', 2011 Brigham Young University Law Review (2011), 2203, at 2209.

${ }^{2}$ Decision 1/CP.16, The Cancun Agreements: Outcome of the Work of the Ad Hoc Working Group on Long-term Cooperative Action under the Convention (UN Doc. FCCC/CP/2010/7/Add.1, 15 March 2011) ('Decision 1/CP.16'), at II, paragraph 12.
}

responsibilities and respective capabilities by undertaking [specified actions]'. ${ }^{3}$ The term 'adaptation' has nuances that vary among different writers, but the Intergovernmental Panel on Climate Change (IPCC) has provided a useful working definition:

Adaptation refers to adjustments in ecological, social, or economic systems in response to actual or expected climatic stimuli and their effects or impacts. It refers to changes in processes, practices, and structures to moderate potential damages or to benefit from opportunities associated with climate change. 4

In this article, the emphasis will be on the 'processes, practices, and structures to moderate potential damages', such as dams to provide water during droughts or reduce flood risks.

The debate over funding for adaptation and the resulting climate agreements has been dominated by a North-South, developing country versus developed country dichotomy. ${ }^{5}$ This article will argue in favour of further differentiation to take into account the special situation of emerging economies, particularly their internal differentiation into rapidly developing and less developed sub-populations.

The term 'emerging economies' has not been assigned any explicit legal meaning, nor is it a technical term among economists. Emerging economies have varying income levels, but many are now middle income or undergoing rapid growth, or both. ${ }^{6}$ These countries are not akin to less developed countries like Bangladesh or the Congo. But neither are they developed countries. This intermediate status is the main characteristic of emerging economies because they have either moved their per capita incomes above the typical developing

\footnotetext{
${ }^{3}$ Ibid., at II, paragraph 14.

${ }^{4}$ See <http://unfccc.int/focus/adaptation/items/6999.php>.

${ }^{5}$ See M.J. Mace, 'Adaptation under the UN Framework Convention on Climate Change: The International Legal Framework', in: W.N. Adger, J. Paavola, S. Huq and M.J. Mace (eds.), Fairness in Adaptation to Climate Change (MIT Press, 2006), 53.

${ }^{6}$ Emerging Economies Economy Watch, found at: <http:// www.economywatch.com/world_economy/emerging-markets/>, references several lists of emerging economies.
} 
country level or have such rapidly growing economies that middle-income status seems within reach in the near future. Perhaps the most notable result is the emergence of substantial middle-class populations, unlike the stark dichotomy between the truly wealthy and the poor that can be found in many developing countries. As we will see, to varying degrees, emerging economies are confronted with serious climate impacts. This leads to new questions: What are their 'common but differentiated responsibilities' in terms of adaptation efforts? What distinctive issues do they face? Do different groups or regions within emerging economies have 'common but differentiated responsibilities' regarding adaptation?

It seems obvious enough that the intermediate economic status of emerging economies attenuates their claim to developing country treatment, suggesting a lower priority for assistance from developed countries than the classic developing country paradigm. Their economic status also means that they have more capacity to adapt than less developed countries. But income within emerging economies does not rise uniformly, and averages can be misleading. Instead, the incomes of some groups may be rising quickly and those of others more slowly.

The existence of large populations with very different economic positions means that we cannot simply view emerging economies as midway between developed and developing countries. Average incomes may have risen, but there may be a bimodal distribution in which one group has moved up a lot and another only a little. That bimodal distribution is itself a distinctive feature that echoes the international divide between developed and developing countries.

In a nutshell, this article will focus on the implications of uneven development within emerging economies for climate adaptation. ${ }^{7}$ The result of this dramatic unevenness, which often separates urban from rural populations, is that emerging economies contain two large groups: one that is enjoying rapid economic growth and begins to see the potential for attaining something akin to developed country lifestyles, and another that is lagging behind and is still more similar to developing country residents. In short, an emerging economy can be seen as containing within itself a quasi-developed country and a quasi-developing one. Of course, the gap is not as large as the North-South divide. Nevertheless, these internal economic divisions are substantial, and they provide a basis for differentiating the responsibilities of emerging economies from the developed/ developing country situations. They also provide a basis

\footnotetext{
${ }^{7}$ For a similar argument in the context of mitigation, see $\mathrm{S}$. Chakravarty et al., 'Sharing Global $\mathrm{CO}_{2}$ Emission Reductions among One Billion High Emitters', 106:29 Proceedings of the National Academy of Science (2009), 11884.
}

for thinking about the "common but differentiated responsibilities' of different groups within the society to fund adaptation measures.

To set the stage for this argument, the article first briefly reviews the global impacts of climate change and the importance of adaptation. It then examines a sample of four emerging economies - China, India, Brazil and Mexico - and shows how climate change will impact them and, in particular, how it will impact rural populations that often have been left behind in the development process. The article next makes the case that wealthier, and often urban, segments of emerging economy populations have a responsibility to assist their poorer counterparts with adaptation. Finally, the article considers some implications in terms of international law.

The thesis of this article is that the bifurcation of development within emerging economies generates distinct responsibilities so that different portions of their societies have 'common but differentiated adaptation responsibilities'. The more developed portion of a society has a duty to assist the less developed portion, just as developed countries have a duty to assist developing countries. Moreover, the governments of emerging economies may have differentiated responsibilities toward different subpopulations, and international mechanisms should be implemented with an eye to the distinctive development gaps typically found inside emerging economies.

\section{CLIMATE CHANGE AND THE NEED FOR ADAPTATION}

Mitigation will affect the degree of adaptation that is ultimately required. But whatever mitigation measures are adopted, a significant degree of climate change seems unavoidable. Indeed, climate change has already taken hold. ${ }^{8}$ Not only is it here to stay, but it will continue to some extent even if we control emissions. As the IPCC has explained, "warming and sea level rise would continue for centuries due to the timescales associated with climate processes and feedbacks, even if greenhouse gas concentrations were to be stabilized'. ${ }^{9}$ Thus, for emerging economies as well as for others, adaptation will be a necessity for generations into the future.

\footnotetext{
${ }^{8}$ See Intergovernmental Panel on Climate Change (IPCC), 'Contribution of Working Group I to the Fourth Assessment Report of the Intergovernmental Panel on Climate Change', in: S. Solomon et al. (eds.), Climate Change 2007: The Physical Science Summary for Policymakers (Cambridge University Press, 2007), at 1.

${ }^{9}$ Ibid., at 17.
} 
With rare exceptions, recent years rank at the top of the list of the warmest global temperatures,${ }^{10}$ and depending on future emissions and climate sensitivity, the world will end up $2-7^{\circ} \mathrm{C}$ warmer than it is today. ${ }^{11}$ Even warming of $2^{\circ} \mathrm{C}$, which may be the best we can hope for, would leave the earth warmer than it has been in millions of years. ${ }^{12}$

Clearly we need to begin assessing and responding to the foreseeable impacts. Sea level rise is one of the most predictable. ${ }^{13}$ Apart from the poorly understood possible contribution of melting from Greenland and Antarctica, ${ }^{14}$ the simple change in temperature of the oceans will contribute to thermal expansion. ${ }^{15}$ This increase in sea levels will result in loss of coastal lands, ${ }^{16}$ inundation of some estuary systems with salt water, salt water intrusions into some drinking sources and increased exposure to flood damage. ${ }^{17}$ Other changes are also foreseeable. Snow cover will decrease in most areas,$^{18}$ and oceans will become increasingly acidic. ${ }^{19}$ Extreme events such as fires, floods and heat waves will become more widespread. ${ }^{20}$

Extreme events are an important focus of adaptation efforts: 'Extreme events such as floods and drought cause extensive damage to many parts of society, and thus a critical issue for adaptation is the degree to which frequency, intensity, and persistence of extreme events

\footnotetext{
${ }^{10}$ D. Archer and S. Rahmstorf, The Climate Crisis: An Introductory Guide to Climate Change (Cambridge University Press, 2010), at 43.

${ }^{11} \mathrm{Ibid}$., at 129 .

${ }^{12} \mathrm{Ibid}$., at 225.

${ }^{13}$ See, e.g., K. Hasselmann et al., 'The Challenge of Long-term Climate Change', 302:5652 Science (2003), 1923, at 1924 (Figure 2) (predicting a two-meter increase in sea level under a 'business as usual' scenario by 2100 , but only 20 centimeters under an optimum regulatory strategy).
}

${ }^{14}$ On the potential for catastrophic melting in these areas, see $\mathrm{N}$. Stern, The Economics of Climate Change: The Stern Review (Cambridge University Press, 2007), at 16; IPCC, n. 8 above, at 16.

${ }^{15}$ Changes in ocean temperature will also affect fish stocks. See H.O Pörtner and R. Knust, 'Climate Change Affects Marine Fishes through the Oxygen Limitation of Thermal Toleration', 315:5808 Science (2007), 95.

${ }^{16}$ A.B. Pittock, Climate Change: Turning Up the Heat (Routledge, 2005) gives examples, including China (at 264), India, Pakistan, Bangladesh (at 268) and the United States (at 278)

${ }^{17}$ See E. Kolbert, Field Notes from a Catastrophe: Man, Nature and Climate Change (Bloomsbury USA, 2006), at 123-124 (British governmental study indicating that what are now hundred-year floods could become routine by late in this century). See also A.B. Pittock, $n$. 16 above, at 118 (stating that without adaptive measures, annual flood losses would increase from £1-24 billion in different scenarios).

${ }^{18}$ See D. Archer and S. Rahmstorf, n. 10 above, at 147.

${ }^{19}$ Ibid., at 148 .

${ }^{20}$ Ibid., at 174; H. Cullen, The Weather of the Future: Heat Waves, Extreme Storms and Other Scenes from a Climate-changed Planet (Harper, 2010). On flooding issues, see H.C. Kunreuther and E.O Michel-Kerjan, At War with the Weather: Managing Large-scale Risks in a New Era of Catastrophes (MIT Press, 2009), at 11-12 (discussing the impact of climate change on catastrophic weather events). change. ${ }^{21}$ The list of potential disasters is a long one, including 'heat waves, droughts, crop failures, wildfires, and outbreaks of illness'. ${ }^{22}$ Besides the direct threat to human life and property, impacts on agriculture could be severe due to '[i]ncreased pests, water stress, diseases, and weather extremes'. ${ }^{23}$

In assessing the impacts of extreme events, it is important to keep in mind that the 'fatality burden of natural disasters is borne disproportionately by developing countries, and mortality in these countries can be high'. ${ }^{24}$ Low-income countries are home to one-third of the global population but experience two-thirds of the fatalities. ${ }^{25}$ In terms of purely economic losses, "when differences ... in economic development are removed, India and China then account for 90 percent of total damages'. ${ }^{26}$ As we will see in more detail below, other emerging economies also face serious climate impacts.

National governments are now beginning to consider how to adjust to these changes. Hopefully, mitigation efforts will limit the extent of future impacts - and it should go without saying that mitigation should be an international priority - but some degree of adaptation will be required in any event.

\section{ADAPTATION ISSUES WITHIN EMERGING ECONOMIES}

Emerging economies are by no means immune from the impacts of climate change. As we will see, they face substantial impacts, which are often most severe in terms of rural populations that are heavily dependent on agriculture that are exposed to severe weather events.

\section{CHINA}

Although at one time it was believed that climate change would have only modest impacts on China, the current understanding is very different. As elsewhere, climate change has already begun. The Chinese government reports that the frequency of heat waves in summer has increased and droughts have worsened in some areas, especially in northern China; heavy pre-

\footnotetext{
${ }^{21}$ W.E. Easterling III, B.H. Hured and J.B. Smith, Coping with Global Climate Change: The Role of Adaptation in the United States (Pew Center, 2004), found at: <http://www.c2es.org/docUploads/ Adaptation.pdf $>$, at 17 .

${ }^{22}$ See R.M. Verchick and A. Hall, n. 1 above, at 2207.

${ }^{23}$ Ibid.

${ }^{24} \mathrm{C}$. Kousky, Informing Climate Adaptation: A Review of the Economic Costs of Natural Disasters, Their Determinants and Risk Reduction Options (Resources for the Future, 2012), found at: <http:// www.rff.org/Publications/Pages/

PublicationDetails.aspx?PublicationID=21945>, at 15 .

${ }^{25}$ Ibid.

${ }^{26}$ Ibid., at 16 .
} 
cipitation has increased in southern China; and the snow disaster has became [sic] more frequent in western China'. ${ }^{27}$

The Chinese government notes that 'discernible adverse impacts on ... agriculture and livestock industry' have already begun. ${ }^{28}$ The effects include

increased instability in agricultural production, severe damages to crops and livestock production caused by drought and hot extremes and heat waves in some parts of the country, aggravated spring freeze injury to earlybudding crops due to climate warming, decline in the yield and quality of grasslands, and augmented losses caused by meteorological disasters.

As we will see in the next section, agricultural regions in China and other emerging economies retain the characteristics of developing countries even as urban areas spring forward in the development process.

Food supply is an urgent concern given China's vast population. China projects a likely drop in the

yield of the three major crops - wheat, rice and corn; changes in the agricultural production layout and structure; accelerated decomposition of organic carbon in the soil; enlarged scope of crop diseases and insect outbreaks; accelerated potential desertification trend of grasslands; increasing frequency of natural fire; decreasing livestock productivity and reproductive ability; and growing risk of livestock disease outbreak. ${ }^{29}$

The impact will be heavily felt by rural agricultural populations and by poorer city residents who cannot afford higher food costs.

In the water sector, Chinese officials note that the overall water supply of the Yellow, Huaihe, Haihe and Liaohe rivers in northern China has decreased significantly, while water supply in southern China has slightly increased. Chinese officials report increased flooding and droughts. ${ }^{30}$ Looking ahead, they predict that climate change could reinforce the drought trend in northern China and intensify water scarcity and imbalance between water supply and demand. ${ }^{31}$ Indeed, China's water problems already seem to be escalating rapidly. ${ }^{32}$ These water issues have the most immediate impact on rural populations that depend on agriculture for their livelihoods, whose economic status might

\footnotetext{
${ }^{27}$ Information Office of the State Council of the People's Republic of China, 'China's Policies and Actions for Addressing Climate Change' (October 2008), found at: <http://www.ccchina.gov.cn/WebSite/ CCChina/UpFile/File419.pdf>, at 3-4.

${ }^{28} \mathrm{lbid}$., at 7 .

${ }^{29} \mathrm{lbid}$., at $7-8$.

${ }^{30} \mathrm{Ibid}$., at 9 .

${ }^{31}$ lbid

${ }^{32}$ R.S. Eshelman, 'China Faces a Water Crisis that Could Worsen without Coordinated Government Response - Study', E\&E News (10 August 2012), found at: <http://www.eenews.net/climatewire/2012/ $08 / 10 / 4>$.
}

qualify them for developing country status if they were independent nations.

Coastal populations are also vulnerable. Chinese authorities report an 'accelerating trend of sea level rise' over the last three decades, which has caused 'seawater intrusion, soil salinization and coastal erosion', has damaged the ecological systems of coastal wetlands, mangroves and coral reefs, and has diminished the service functions and bio-diversity of ecological system in coastal area'. ${ }^{33}$ Furthermore, authorities posit that climate-induced rises in sea temperature and carbondioxide-induced ocean acidification may have caused 'oxygen-impoverished zones in part of maritime areas, the degradation of marine fishery and rare and endangered species resources' ${ }^{34}$ Fishing communities will be directly impacted to a greater extent than more affluent urban populations. Continuing sea level rise will 'undermine the capacity of public drainage facilities in coastal cities, and impair the functions of harbors' ${ }^{35}$ Here, the threat is likely to impact most heavily on poorer residents who lack the means to relocate to higher ground.

Overall, Chinese government reports are far from sanguine about the potential impacts of climate change. The government's prediction is that 'climate change will also produce far-reaching impacts on society, economy and other fields, and cause huge losses to the national economy'. Finally, China predicts increased 'threats to the safety of life and property, and to the normal order and stability of social life'. ${ }^{36}$ Recent floods in Beijing, which killed almost 40 people and caused US $\$ 1.6$ billion in damage, demonstrate the seriousness of the potential risks. ${ }^{37}$

\section{INDIA, MEXICO AND BRAZIL}

In India, the potential impacts are even grimmer than in China. ${ }^{38}$ Water supplies are likely to be impacted and will pose special problems because water resources are already stressed in many parts of the country, and climate change will only exacerbate the situation. The gross per capita water availability in India is projected to decline from approximately 1,820 cubic meters per year in 2001 to as low as approximately 1,140 cubic

\footnotetext{
${ }^{33}$ Information Office of the State Council, n. 7 above, at 9-10.

${ }^{34}$ Ibid., at 10.

${ }^{35} \mathrm{lbid}$.

${ }^{36} \mathrm{lbid}$.

${ }^{37}$ 'Weekend Floods in Beijing Kill at Least 37 , Cause $\$ 1.6 \mathrm{~B}$ in Damage', E\&E News (24 July 2012), found at: <http://www.eenews. net/climatewire/2012/07/24/archive/8?terms=weekend+floods+in+ beijings.

${ }^{38}$ A. Rosencranz, D. Singh and J. Pai, 'Climate Change Adaptation, Policies and Measures in India', 22:3 Georgetown International Environmental Law Review (2010), 575.
} 
meters per year in 2050. ${ }^{39}$ Combined with the direct temperature changes associated with climate change, increases in droughts and floods, decreased irrigation water and decreased average water supply may lead to reductions of $10 \%$ of the wheat crop, posing a risk to food security. $4^{40}$ Thus, once again, the less developed, rural areas will be the most heavily impacted. Climate change will also intensify existing public health problems such as malaria and dengue fever by providing new habitat for insect vectors. ${ }^{41}$

India may already be experiencing harm from climate change. In 2012, the country experienced its second drought in four years, with sharply reduced agricultural production in areas in the north and west, and in Punjab rainfall was $70 \%$ below normal. ${ }^{42}$ The drought may have contributed to a massive blackout affecting half of the country as farmers turned to electric groundwater pumps. ${ }^{43}$ Although these droughts may simply be due to normal weather variations, climate scientists predict larger extremes and less even distribution of rainfall. ${ }^{44}$ These risks clearly fall most heavily on rural populations that are dependent on agriculture and on poorer segments of the urban population that lack access to sanitation and clean water. These groups are disadvantaged to begin with, while other segments of society may be much less exposed to these risks.

In Mexico, a multitude of impacts are predicted. Significant ecosystem changes are expected, which will be especially serious for rural and indigenous peoples. Tropical forest will be replaced by savannahs in central and southern Mexico, with a shift from semi-arid to arid vegetation in most of central and northern Mexico due to synergistic effects of both land use and climate changes (medium confidence). In tropical forests, species extinctions are likely. ${ }^{45}$ Mexico will 'experience significantly more severe droughts, floods, and storms including hurricanes'. Yet at the same time, overall precipitation is expected to decline by up to $8 \%$ in some regions. ${ }^{46}$ Northwestern Mexico, the most arid part of the country, is 'expected to suffer many very serious

\footnotetext{
${ }^{39} \mathrm{lbid}$., at 580 .

${ }^{40}$ Ibid., at 581

${ }^{41} \mathrm{lbid}$., at 584

${ }^{42}$ R.S. Eshelman, 'India's Drought Punishes Farmers, Highlights Challenges to Climate Change Adaptation', E\&E News (3 August 2012), found at: <http://www.eenews.net/climatewire/2012/08/03/ archive/1?terms-india $\% 27 \mathrm{~s}+$ drought+punishes+farmers $>$.

${ }^{43} \mathrm{Ibid}$.

44 Ibid.

${ }^{45}$ WWF, 'Climate Change Impacts in Mexico' (undated), found at: $<$ http://wwf.panda.org/about_our_earth/aboutcc/problems/rising temperatures/hotspot_map/mexico.cfm>.

${ }^{46} \mathrm{Geo}$ Mexico, 'Expected Impact on Mexico of Global Climate Change' (22 December 2010), found at: <http://geo-mexico.com/ $? \mathrm{p}=3216>$.

droughts' ${ }^{47}$ Obviously, less rainfall and greater variability will have major impacts on Mexican agriculture, especially in the drier western areas.

Less information is available about climate impacts in Brazil, but the information that does exist suggests significant issues. There is particular concern about the Amazon rain forest and Pantanal wetlands, as well as general concerns about increased flooding and the impact of sea level rise. In addition, '[c]hanging rainfall patterns, especially in the drought-affected northeastern region ... will mean poorer water resources and a reduced water supply'. ${ }^{48}$ The poorest elements of the population will have the least resources with which to adapt to these changes.

To varying degrees, then, emerging economies all face challenges from climate change. Those challenges may be more serious for some (such as India) than for others (such as Brazil). Emerging economies are not alone in being exposed to climate impacts, but their internal economic divisions create a distinctive issue of social equity. Many of these harms fall most heavily on rural populations reliant on agriculture or on impoverished segments of urban populations. They are yet to benefit from the rapid development that has moved other segments of the population out of poverty and lack the resources to adapt to climate change. The next section considers the extent to which responsibility for adaptation may fall on national governments, financed in significant part by wealthier regions and populations, as opposed to poorer populations within emerging economies.

\section{RELATIVE RESPONSIBILITY FOR ADAPTATION WITHIN EMERGING ECONOMIES}

Adaptation will not be cheap. A key question is how financial responsibility should fall on beneficiaries of adaptation or be shifted to areas with more financial capacity or greater responsibility for emissions. So far, this issue has mostly played out at the international level in the form of claims that developed countries should finance adaptation in developing countries. But in a reduced form, the same issue exists within emerging economies because of their internal economic divides. The question is: Should more developed, rapidly growing regions and populations fund adaptation for regions and populations with much lower incomes and emissions?

\footnotetext{
${ }^{47}$ Ibid.

${ }^{48}$ E. Lèbre La Rovere and A. Santos Pereira, 'Brazil and Climate Change: A Country Profile' (14 February 2007), found at: <http:// www.scidev.net/en/policy-briefs/brazil-climate-change-a-countryprofile.html>
} 
This section starts with a brief discussion of development disparities within emerging economies. This is followed by an evaluation of the arguments for leaving the economic cost of adaptation on affected regions rather than the country as a whole. The section then makes the case for an important national role in emerging-economy adaptation, which in effect means that wealthier populations will help fund adaptation in poorer ones.

\section{THE BIMODAL CHARACTERISTIC OF EMERGING ECONOMIES}

One striking feature of emerging economies is the existence of large populations with very different economic characteristics, creating a kind of dual economy. Often, this is a city versus countryside question. Income inequality has been rising in China and India. ${ }^{49}$ Mexico has also experienced rising income inequality. According to an International Monetary Fund report,

[r]ural poverty accounts for nearly 63 percent of poverty worldwide, reaching 90 percent in countries like China.... The exceptions are several countries in Latin America in which much of the poverty is in urban areas. In almost all countries, there is a higher incident of poverty in rural than in urban areas and the conditions of the rural poor are far worse than those of the urban poor in terms of personal consumption levels and access to health care, potable water and sanitation, housing, transport, and transportation..$^{50}$

Despite remarkable economic growth in China, the gulf between urban and rural populations remains large:

In 2010, rural residents had an annual average per capita disposable income of 5,900 yuan (US\$898). That's less than a third of the average per capita disposable income of urban residents, which stood at 19,100 yuan (US\$2,900)..$^{51}$

Indeed, '[f]or both China and India, poverty rates are higher in rural than in urban areas. In addition, rural areas are still home to most of the total population. Poverty is thus concentrated in rural areas. ${ }^{52}$

\footnotetext{
${ }^{49}$ Income inequality has increased in the four most populated nations in the world: China, India, the former Soviet Republic and the United States. In the first three nations, the growth in income inequality followed economic liberalization. These nations contain more than half the world's population, and thus rising inequality in them portends rising average inequality in the remainder of nations, absent evidence of greatly declining equality across them.

${ }^{50}$ M.H. Khan, 'Rural Poverty in Developing Countries', IMF Working Paper (April 2000), found at: <http://www.imf.org/external/pubs/ft/wp/ 2000/wp0078.pdf>, at 6 .

${ }^{51} \mathrm{D}$. Tobin, 'Inequality in China: Rural Poverty Persists as Urban Wealth Balloons', BBC News (29 June 2011), found at: <http:// www.bbc.co.uk/news/business-13945072>.

${ }^{52}$ S. Fan, C. Chan-Kang and A. Mukherjee, Rural and Urban Dynamics and Poverty: Evidence from China and India (International Food Policy Research Institute, 2005), found at: <http://www.ifpri.org/ publication/rural-and-urban-dynamics-and-poverty- $0>$, at iii.
}

Sharp distinctions in development levels between rural and urban populations are directly relevant to climate adaptation. As we have seen, rural populations are often the most threatened by climate change because of their dependence on agriculture. Changes in precipitation and water availability pose a major threat to these populations, along with potential heat waves threatening crops and livestock, and the spread of pests that may be caused by climate change.

In Mexico, too, poverty is not evenly distributed. In general, 'the southern half of Mexico (excluding the Yucatán Peninsula) is much less wealthy in economic terms and social indicators than the north' ${ }^{53}$ Indeed, in four Mexican states, more than $40 \%$ of the population lives in extreme poverty. In Brazil, the disparity between urban and rural areas is less extreme, but

Brazil has about 18 million poor rural people, the largest number in the Western Hemisphere. And Brazil's NorthEast region has the single largest concentration of rural poverty in Latin America. ... . In this region, 58 percent of the total population and 67 percent of the rural population is poor. ${ }^{54}$

There are also important divisions between groups within developing countries in energy use - and thus in responsibility for carbon emissions. ${ }^{.5}$ There is 'a general trend seen throughout the developing world: as households come out of poverty and enter the middle class, they purchase new assets, many of which use substantial amounts of energy'. ${ }^{56}$ For example,

in Brazil, Mexico, and urban China, growth in refrigerator ownership at the lower end of the income distribution was faster than growth at the higher end. .. . The next row, for rural China, depicts slower growth at the low end of the income distribution. Poor households in rural China, however, were much poorer than their counterparts in Brazil, Mexico or urban China and began in the 1990 s with many fewer refrigerators per household. ${ }^{57}$

Given the fact that some populations have not only substantially higher wealth but also greater responsibility for carbon emissions, we must consider the implications for adaptation responsibilities. We begin by considering the argument for allocating responsibility for adaptation to climate change onto the shoulders of the regions and communities suffering the impacts, which often means leaving poorer regions or the countryside to fend for themselves.

\footnotetext{
${ }^{53}$ Geo Mexico, 'Is Poverty in Mexico on the Rise?' (6 September 2011), found at: <http://geo-mexico.com/?p=5075>.

${ }^{54}$ Rural Poverty Portal, 'Rural Poverty in Brazil', found at: <http:// www.ruralpovertyportal.org/web/rural-poverty-portal/country/home/ tags/brazil>.

${ }^{55} \mathrm{C}$. Wolfram, O. Shelef and P. Gertler, How Will Energy Demand Develop in the Developing World? (Energy Institute at Haas, January 2012), found at: <http://ei.haas.berkeley.edu/pdf/working_papers/ WP226.pdf>

${ }^{56} \mathrm{lbid}$., at 2.

${ }^{57}$ lbid., at 5 .
} 


\section{LOCAL FUNDING UNDER THE 'BENEFICIARY PAYS' PRINCIPLE}

It is easy to construct an argument in favour of leaving the financial responsibility for climate adaptation with localities that have little choice but to adapt as well as they can in the absence of outside assistance. Normally, people have to pay for goods and services if they want to consume them - at least, this is the theory of a market economy. When the private market is unable to produce certain goods, perhaps because of collective action problems, the government steps in. But the basic principle that the costs of producing goods should be borne by those who benefit from them remains appealing. Moreover, adaptation needs will vary with local conditions, which are best understood by the local population that will benefit from an adaptation project. ${ }^{58}$ According to this theory, the individuals who benefit from adaptation should pay the cost. Usually, this will translate into State financing of adaptation efforts that benefit local citizens.

On an analogous issue in the theory of taxation, Eric Rakowski suggests that

[a] nation committed to protecting its citizens as equals will attempt to maintain its borders and to supply people living throughout its territory with basic protection. But it cannot fully equalize protections throughout, at least not if it taxes all the same, so that those who choose to live in certain areas know that they take on some risks and costs, perhaps including private protection, as the price of their decisions. Privately purchased protection or the assumption of additional risk, coupled with equal taxes, is tantamount to equal protection with unequal tax payments. ${ }^{59}$

In simpler terms, the argument is that people who choose to live in riskier areas cannot fairly demand that their fellow citizens pay to provide them protection from these risks. We can call this the 'beneficiary pays' principle.

The 'beneficiary pays' principle would seem to call for placing the responsibility for adaptation at the lowest possible governmental level so that both costs and benefits would be concentrated on the same group. Thus, coastal measures might be financed by coastal localities, while agricultural issues would be addressed by rural areas. For instance, if new varieties of wheat are needed because of climate change, wheat farmers might pay a special fee to help develop the new varieties. Or if a flood zone needs additional levees, landowners might pay a special tax.

\footnotetext{
${ }^{58}$ R. Glicksman, 'Climate Change Adaptation: A Collective Action Perspective on Federalism Concerns', 30:4 Environmental Law (2010), 1159 , at 1164

${ }^{59}$ E. Rakowski, 'Can Wealth Taxes be Justified?', 53:3 Tax Law Review (2000), 263, at 305, n. 75.
}

The 'beneficiary pays' principle is an appealing principle in terms of eliminating moral hazard and rent seeking. If project beneficiaries have to pay for projects, they are unlikely to over-invest beyond the project's benefits or to lobby the government for projects that will raise their taxes more than any corresponding benefit they receive. To the extent that we are concerned about over-investment in adaptation, 'beneficiary pays' is the best solution.

On the other hand, 'beneficiary pays' does not advance other important social goals. It provides no incentive for emitters to mitigate. It leaves the costs of climate change where it finds them rather than providing a form of social insurance for those who are hit hardest. Furthermore, to the extent that we view emitters as culpable or unjustly enriched by their failure to mitigate, 'beneficiary pays' does not advance the ethical concept that individuals who cause harm to others should be responsible for recompense. Finally, because benefits and costs fall on the same individuals, 'beneficiary pays' also fails to serve any redistributive goal, and we may be concerned that poorer areas will lack the financial or institutional capacity to manage adaptation. ${ }^{60}$

There are also practical issues to be considered. Determining the beneficiaries of a given project may be straightforward, thus limiting transaction costs. Yet this will not always be true. Adaptation projects may indirectly benefit other sectors of society. For example, a water storage project may primarily benefit users in the immediate area, but it may also offer a potential fallback supply to other users in unusual drought conditions. This is a particularly significant question with large water bodies such as the Yangtze or Ganges. Or adaptation in one area may prevent local residents from moving elsewhere, which would have created the need for public services and infrastructure in those locations.

'Beneficiary pays' clearly supports local responsibilities when beneficiaries of an adaptation measure are truly localized, and when mitigation incentives, loss spreading and just desserts are not relevant. But, as we have seen, many climate impacts are widespread across regions and hit vulnerable populations the hardest, while wealth distribution is highly unequal in emerging

\footnotetext{
${ }^{60}$ Whether these are serious shortcomings depends in part on whether these other social goals are viewed as important. It also depends on whether we have alternative methods to advance those goals. For example, if we have optimum mitigation requirements, complete insurance for all risks and a fiscal system that achieves our desired income distribution, we do not need to rely on adaptation financing to help achieve those goals. Some might also think that ensuring just deserts is not a valid goal for social policy, or that the circumstances of climate change are not such as to involve any principle of just deserts. Thus, evaluating the normative appeal of the 'beneficiary pays' principle may be complicated.
} 
economies. Next, we consider the implications of these facts in terms of national responsibility.

\section{NATIONAL RESPONSIBILITY WITHIN EMERGING ECONOMIES}

The alternative to local responsibility is for the cost of adaptation to fall on the national government (using either domestic funds or funds from international transfers). ${ }^{61}$ The underlying principle could be called 'taxpayer pays', and rests on the premise that society as a whole should protect individuals from certain kinds of harm. This system achieves the maximum amount of loss spreading. It expresses the idea that climate change is a national problem, thus emphasizing national solidarity in the face of the threat. To the extent we are satisfied with the tax system in distributional terms, it also provides the right distributional result for climate costs. Finally, where adaptation measures have spillover effects between different localities, national responsibility may be more effective. ${ }^{62}$

This principle could be implemented in several ways. The national government might simply take adaptation as its own responsibility and pay for projects. Alternatively, local governments might receive national grants to engage in adaptation, or private actors might receive tax credits or other subsidies.

Although it rates well in terms of loss spreading, national funding is problematic along other dimensions. It maximizes the potential for moral hazard and rent seeking since financial responsibility for adaptation is uncoupled from receipt of benefits. In the worst case scenario, climate adaptation might become one of the biggest pork barrels in history.

Use of national funds rather than local funds may be particularly attractive when it can be used as a mechanism to shift adaptation costs on emitters within the country. This can be justified on the basis of fairness. Prior to the last quarter of the twentieth century, emitters may not have had strong grounds for believing that their conduct would cause serious harm. Nevertheless, the fact remains that they have caused harm, and in the process, they have enjoyed lower energy costs than they would have incurred by using alternative technologies or by reducing output. Thus, there is a potentially plausible basis for reallocating some adaptation costs to emitters, which could be more easily done at the national level rather than locally. As Paul Baer points

\footnotetext{
${ }^{61}$ For present purposes, it is irrelevant whether the government finances projects directly through taxes or by issuing bonds, which will later result in payments financed through taxes. It would make a difference, however, if imperfections in the bond market allowed the government to transfer some of the costs away from taxpayers to bondholders.

${ }^{62}$ See R. Glicksman, n. 58 above, at 1165 .

(c) 2013 Blackwell Publishing Ltd.
}

out, this rationale supports 'net liability for adaptation from wealthy classes in the South', as well as from North to South. ${ }^{63}$

In short, national financing of adaptation is appealing when the need for adaptation is easily monitored (reducing the incentive to rent seek), when there is little risk that adaptation will cause undesirable reductions in self-protective action by beneficiaries, when doing so addresses wealth inequalities between sub-populations, and when the cost can be shifted to emitters. When infrastructure projects affect multiple localities, a national financing role is appropriate.

These arguments point toward a real, albeit limited national role. Adaptation projects should not be nationally funded when there are no spill-overs, no obstacles to State provision of the adaptation, and no strong claim for national solidarity. But this leaves a substantial category of cases in which national funding is appropriate. In emerging economies, the case is especially strong for distributional reasons because of the gap between fast-developing and slow-developing regions, and because fast-developing regions have more responsibility for the carbon emissions that are causing the problems. In addition, as compared with developed countries, emerging economies may have more reason to worry about social solidarity as the disparities in development trajectories threaten to reduce a sense of societal unity. As noted earlier, this argument applies whether the country's adaptation funds are generated internally or come from transfers from other countries.

\section{INTERNAL ADAPTATION RESPONSIBILITIES OF EMERGING ECONOMIES UNDER INTERNATIONAL LAW}

As we have seen, the duality of emerging economies makes an especially strong case for national responsibility in terms of climate adaptation. In particular, this means responsibility toward the economically lagging 'country within a country'. What does this mean for international law? This section provides a tentative exploration of some of the potential avenues for analyzing this question.

From the perspective of international law, the notion of responsibility for adaptation funding finds fundamental support in the concept of State responsibility. States have a responsibility to prevent activities in their territories (such as carbon emissions) that harm other States and to provide redress to the affected State when

${ }^{63}$ P. Baer, 'Adaptation: Who Pays Whom?', in: W.N. Adger et al., n. 5 above, 132. 
such harm takes place. ${ }^{64}$ The principle of State responsibility provides limited assistance in considering situations involving internal divisions within countries. Compensation by developed to emerging economies, if any, would be paid to the affected State, which might or might not use the funds to assist adaptation in the most impacted or poorest regions. Moreover, the principle of State responsibility does not speak to the responsibilities of one portion of a State for damage to another portion. As with traditional international law generally, the principle speaks only to external relationships between States.

While the principle does not apply directly, however, it does suggest by analogy at least that high carbon emitters should have a responsibility to compensate and assist adaptation by the poorest and most vulnerable populations, regardless of international boundaries. But to establish legal bases for such responsibilities, we must look to sources of law beyond the principle of State responsibility.

\section{CLIMATE AGREEMENTS}

The most relevant provisions of international law are the international climate agreements and their interpretation, which can be informed by understanding the unique position of emerging economies. The term 'common but differentiated responsibilities and respective capabilities' initially contemplated the distinction between developed and developing countries in both the mitigation and adaptation contexts. It is now widely recognized that this dichotomy is out of date in terms of mitigation, ${ }^{65}$ but it is also too simplistic for understanding adaptation. Emerging economies have some similarity to developing countries, and should not be confused with developed countries. As we have seen, however, emerging economies have distinctive internal responsibilities because of the gap between different population segments and regions. This distinctive status should be taken into account in interpreting responsibilities under the United Nations Framework Convention on Climate Change (UNFCCC) and the Cancún Agreements.

One possibility might be to interpret the concept of 'common but differentiated responsibilities' so as to make domestic redistribution a condition for international assistance. Under this approach, the responsibility of developed countries to assist with adaptation

\footnotetext{
${ }^{64}$ R.S.J. Tol and R. Verheyen, 'State Responsibility and Compensation for Climate Change Damages: A Legal and Economic Perspective', 32:9 Energy Policy (2004), 1109, at 1110-1111.

${ }^{65}$ See, e.g., S. Chakravarty et al., note 7 above; C. Stone, 'Common but Differentiated Responsibilities in International Law', 98:2 American Journal of International Law (2004), 276; J.C. Nagle, 'How Much Should China Pollute?', 12:3 Vermont Journal of Environmental Law (2011), 591.

(c) 2013 Blackwell Publishing Ltd.
}

would not be triggered until the recipient countries first assured a fair distribution of income. But this approach seems problematic. Such a requirement might well result in developing countries refusing adaptation assistance so as to protect wealthy elites from redistribution, which would be a perverse outcome. A redistribution requirement might also be seen as a dramatic intrusion on sovereignty and domestic governance by major emerging economies such as China and India. In any event, adaptation funding seems like too weak a lever to have a realistic prospect of sparking major redistribution within emerging economies.

Less ambitiously, international funding for emerging economies could be conditioned on the recipient country providing resources for adaptation to its less developed subpopulation. The UNFCCC's provisions on developed countries requirements to provide new and additional finance contains no basis for such conditionalities. ${ }^{66}$ Thus, a new agreement would be necessary. In any event, as a practical matter, this approach is likely to have little practical impact. The reason is simply that emerging economies are likely in any event to be a lower priority for international funding agencies as they seek to allocate their limited resources. For instance, the Green Climate Fund is required by its governing document to give special consideration to

the urgent and immediate needs of developing countries that are particularly vulnerable to the adverse effects of climate change, including [least-developed countries], [small island developing States] and African States, using minimum allocation floors for these countries as appropriate. ${ }^{67}$

Unfortunately, financing from developed countries is likely to be limited, so these high priority countries are likely to use up the bulk of available funds, leaving at best smaller amounts for emerging economies and perhaps nothing at all. One could certainly fashion an argument that the less developed parts of emerging economies may have urgent needs that should be treated on parity with similarly poor areas in developing countries, but to the extent that the national governments in emerging economies have sufficient resources to assist their less developed areas, the argument for international assistance seems weaker.

Ideally, the distinctive status of emerging economies should be more explicitly flagged in future adaptation agreements, which should recognize more nuanced explicit distinctions between countries than the conventional North/South, developed/developing

\footnotetext{
${ }^{66}$ United Nations Framework Convention on Climate Change (New York, 9 May 1992; in force 21 March 1994) ('UNFCCC'), Article 4.3 ${ }^{67}$ Governing Instrument for the Green Climate Fund, found at: <http:// gcfund.net/fileadmin/00_customer/documents/pdf/GCFgoverning_instrument-120521-block-LY.pdf>, Article E(52).
} 
dichotomy. If this is not politically feasible, it may be possible to address the special needs of the 'laggard', often rural populations of emerging economies without explicitly singling out emerging economies as a defined category. For instance, climate agreements might highlight the need to address the special problems of rural populations, the needs of individuals displaced by climate change or regions lacking the resources for adaptation compared with a country as a whole.

One particularly promising possibility involves ties between adaptation funding and mitigation measures. ${ }^{68}$ Emerging economies receiving funding from selling carbon allowances or providing offsets (such as those under the current Clean Development Mechanism) could be required to dedicate some percentage of the proceeds to fund adaptation measures on behalf of disadvantaged regions or subpopulations within their own countries. Alternatively, some percentage of the proceeds allocated to the Green Climate Fund, the Global Environment Facility or a similar international institution could act as a conduit for those funds to be redirected back to the less developed areas within emerging economies for adaptation purposes. Although levies to fund adaptation are not a novelty, the innovation consists of targeting adaptation to specific regions within emerging economies and possibly obtaining some of the financing from funds that would otherwise be received by emerging economies at the national level.

\section{HUMAN RIGHTS LAW}

We might also consider how international human rights might provide a prism for understanding the needs of laggard populations within emerging economies. So far, efforts to invoke human rights law seem to be at an early stage, but they may have some longrange applicability to the situation of emerging economies. Climate change clearly impacts human rights to food, water and shelter. ${ }^{69}$ Thus, there is at least a conceptual basis for invoking human rights law as an independent source of obligations in considering adaptation.

It is worth exploring, if only preliminarily, the basis for a human or minority right to resilient infrastructure and whether such a right could be legally used to ask

\footnotetext{
${ }^{68}$ For a listing of current sources of adaptation funding, see UNFCCC, 'Adaptation Funding' (undated), found at: <http://unfccc. int/adaptation/implementing_adaptation/adaptation_funding_ interface/items/4638.php>.

${ }^{69}$ See M.J. Hall and D.C. Weiss, 'Avoiding Adaptation Apartheid: Climate Change Adaptation and Human Rights Law', 37:2 Yale Journal of International Law (2012), 309, at 331-335; S.L. Kass, 'Integrated Justice: Human Rights, Climate Change and Poverty', 18:1 Transnational Law and Contemporary Problems (2009), 115, at 127
}

(C) 2013 Blackwell Publishing Ltd. action from the State or, at least, to claim priority in the allocation of international adaptation aid. The basis for such a right could be found in arguments for a human right to disaster prevention and relief. ${ }^{70}$ The rationale for recognizing a right to resilience derives ultimately from Article 3 of the Universal Declaration of Human Rights, which provides that '[e]veryone has the right to life, liberty, and security of person'.$^{71}$ Article 25 provides every person with a right to security and protection of basic needs due to "in the event of . . . circumstances beyond his control' ${ }^{72}$ Climate change is certainly an event beyond any individual's control, as are disasters such as floods or droughts caused by climate change. Indeed, some scholars have recently argued in favour of recognition of a human right to climate adaptation. ${ }^{73}$ They suggest that recognition of this right could help prioritize adaptation funding. ${ }^{74}$ This line of argument is promising, but we are a long way from implementing such a right to climate adaptation or more specifically to resilient infrastructure.

Other human rights claims could be more focused. Impacted groups, especially those who lack the resources to protect themselves from climate change, may be forced to move. For instance, as agriculture becomes more difficult or riskier, rural populations may move elsewhere. Particular attention has been given to the rights of persons who are displaced as a result of climate change, inasmuch as migration is a well-established response to disasters and other adverse events ${ }^{75}$ that will increase with climate change:

[M]any people refer to this class of persons as 'climate migrants' or 'environmentally displaced persons', and seek protection for them through other legal avenues, primarily through domestic law and proposed expansions to the international climate regime. These efforts, however, have proven controversial and largely unsuccessful, leaving these people with minimal legal protections and reliant on inadequate sources of climate change adaptation assistance for relief. ${ }^{76}$

There have been proposals for an international convention to protect these individuals, at least when they

\footnotetext{
${ }^{70}$ See G. Kent, 'The Human Right to Disaster Mitigation and Relief', 3:3-4 Environmental Hazards (2001), 137, at 137; E. Cameron and M. Limon, 'Restoring the Climate by Realizing Rights: The Role of the International Human Rights System', 21:3 Review of European Community and International Environmental Law (2012), 204.

71 Universal Declaration of Human Rights (UNGA Resolution A/RES/ 217A(III), 10 December 1948).

72 Ibid., Article 25.

${ }^{73}$ See M.J. Hall and D.C. Weiss, n. 69 above.

${ }^{74} \mathrm{lbid}$, at 360 .

${ }^{75}$ See L.P. Boustan, M.E. Kahn and P.W. Rhode, 'Moving to Higher Ground: Migration Response to Natural Disasters in the Early Twentieth Century', 102:3 American Economic Review: Papers and Proceedings (2012), 238

${ }^{76} \mathrm{C}$. Carlarne, 'Risky Business: The Ups and Downs of Mixing Economics, Security and Climate Change', 10:2 Melbourne Journal of International Law (2009), 439, at 464.
} 
cross national borders. ${ }^{77}$ Some writers have gone further and called for an international convention that covers internal displacement. ${ }^{78}$ In terms of emerging economies, a convention covering internal displacement may be particularly relevant, because their size and economic prospects may make internal relocation more appealing to people displaced by climate impacts.

Human rights law might also provide some traction for dealing with the needs of vulnerable populations in terms of adaptation. ${ }^{79}$ Among other groups, those in rural areas and poor persons - and in many emerging economies the two groups heavily overlap - 'will likely suffer disproportionate impacts of climate change and thus more severe human rights infringements'. ${ }^{80}$ Human rights claims on this basis can be readily imagined.

Although human rights law may have some direct application to climate adaptation in the future, its effectiveness suffers from well known limits. ${ }^{81}$ Nevertheless, it at least has potential for spotlighting adaptation failures, communicating how they can result in deprivation of basic human needs and emphasizing the special needs of vulnerable populations such as the rural poor in many emerging economies. It is also conceivable that some human rights obligations might be recognized within climate agreements.

For the present, at least, the most significant international law in terms of adaptation by emerging economies is likely to be found in climate agreements themselves, rather than more general legal frameworks. This makes it particularly important to elaborate the concept of 'common but differentiated responsibilities' to provide clearer guidance about the nature of those responsibilities.

Thus, while human rights may have potential application in determining the adaptation responsibilities of emerging economies to their more backward populations, climate agreements provide the clearer avenue for addressing the internal adaptation responsibilities of emerging economies than general international rights law. Even if the treaties do not address this issue specifically as they are reformulated, the general reference to 'common but differentiated responsibilities'

\footnotetext{
${ }^{77}$ B. Mayer, 'The International Legal Challenges of Climate-induced Migration: Proposal for an International Legal Framework', 22:3 Colorado Journal of International Environmental Law and Policy (2011), 357; B. Docherty and T. Giannini, 'Confronting a Rising Tide: A Proposal for a Convention on Climate Change Refugees', 33:2 Harvard Environmental Law Review (2009), 349.

${ }^{78}$ D. Hodgkinson and L. Young, ' "In the Face of Looming Catastrophe": A Convention for Climate Change Displaced Persons' (August 2012), found at: <http://www.ccdpconvention.com/documents/ Updated $\% 20$ treaty\%20proposal.pdfs.

${ }^{79}$ See M.J. Hall and D.C. Weiss, n. 69 above, at 336 .

${ }^{80}$ Ibid.

81 lbid., at 342-343.

should be enough of a foundation for consideration of the unique position of emerging economies.

Such an interpretation would also be supported by considerations of human rights law, providing a synergy between the two approaches. The Cancún Agreement points in this direction by affirming the principle that: 'Parties should, in all climate change related actions, fully respect human rights. ${ }^{82}$ They also affirm the need for consideration of the needs of vulnerable groups and communities during adaptation planning, which could support prioritizing the less developed segments within emerging economies. ${ }^{83}$ Furthermore, the preamble recalls 'resolution 10/4 of the United Nations Human Rights Council on human rights and climate change, which recognizes that the adverse effects of climate change have a range of direct and indirect implications for the effective enjoyment of human rights'. ${ }^{84}$ Thus, apart from whatever independent force it might have in direct application to emerging economies, international human rights law could move the interpretation of 'common but differentiated responsibilities' toward a recognition of the claim of less developed segments of emerging economies to assistance from more developed segments via their national government.

\section{CONCLUSIONS}

Twenty years ago, it may have seemed natural to think about climate policy in terms of a dichotomy between developed countries and developing ones, with both carbon emissions and economic welfare following this division. Today, the situation of emerging economies disrupts this distinction. Not only may they have intermediate economic status, but their current carbon emissions may be far beyond poorer countries and many developing countries.

As we have seen, emerging economies complicate the picture in yet another way: because of their distinctive internal divisions. A common pattern within emerging economies is the combination of some rapidly developing or more affluent regions (often urban) and laggard regions (often rural) with slower development. Because of their lower level of development, laggard regions generally have much lower carbon emissions. Laggard regions also are often quite vulnerable to climate impacts because of their dependence on agriculture and because they lack resources for adaptation. These laggard regions have plausible arguments for adaptation assistance from developing countries and from

\footnotetext{
${ }^{82}$ Decision 1/CP.16, n. 2 above, at I, paragraph 8.

${ }^{83}$ Ibid., Article II, paragraph 12.

${ }^{84}$ Ibid., Preamble, paragraph 7.
} 
their own national governments (and indirectly from the more advanced regions).

The concept of 'common but differentiated responsibilities' may not have originally contemplated this situation, but it is capacious enough to support singling out emerging economies for special legal treatment in the context of adaptation. Such distinctive treatment could include a responsibility for developed countries to fund adaptation specifically in laggard regions of emerging economies, as compared with other regions. Such a responsibility could be embedded in international funding mechanisms for adaptation. Equally important, the 'differentiated adaptation responsibilities' of emerging economies could be translated into an obligation on their own part to fund adaptation in laggard regions.

In terms of legal mechanisms, these outcomes could be accomplished in part simply through interpretation of existing international instruments such as the UNFCCC and the Cancún Adaptation Framework. The argument for such an interpretation is bolstered by principles of international human rights law since, without adaptation, climate impacts threaten core human rights. Going forward, future climate agreements could more explicitly incorporate a responsibility to channel adaptation funding to less developed regions in countries with such internal divisions.

We usually think of climate justice as involving North versus South. It is true that the issues are the most acute at the global level, but emerging economies replicate some of the same issues internally because of the divide between the poor (often rural) and the new middle class (often urban). The gap between lagging areas or populations and rapidly developing ones is reminiscent of the gap between developing and developed countries, though less severe. Thus, even within emerging economies, one might speak of 'common but differentiated responsibilities' to respond to climate change. Fleshing out those responsibilities belongs to the next generation of challenges facing international law in an era of climate change.

Daniel Farber is the Sho Sato Professor of Law at the University of California, Berkeley. He is also the Co-Director of the Center for Law, Energy and the Environment. Much of Professor Farber's current research focuses on the related areas of climate change and natural disasters. He has written extensively about the problems posed by modeling uncertainties for the design of climate policy. He has also written about climate justice, including appropriate mechanisms for funding climate change adaptation. In terms of disaster issues, Professor Farber has pioneered the field of Disaster Law in the United States. This emerging area of law addresses the legal system's responses to catastrophic risks such as earthquakes, nuclear accidents, hurricanes and floods. He is the author of 18 books and nearly 200 articles. His books include Eco-pragmatism: Making Sensible Environmental Decisions in an Uncertain World (University of Chicago Press, 2000), Cases and Materials on Environmental Law (ThomsonReuters, 2006) (with J. Freeman and A. Carlson) and Disaster Law and Policy (Aspen Press, 2010) (with R. Verchick, J. Chen and L. Sun). 